\title{
Lumen
}

Selected Proceedings from the Canadian Society for Eighteenth-Century Studies

\section{Scientific Amusements: Literary Representations of the Birmingham Lunar Society}

\section{Pam Perkins}

Volume 25, 2006

URI : https://id.erudit.org/iderudit/1012077ar

DOI : https://doi.org/10.7202/1012077ar

Aller au sommaire du numéro

Éditeur(s)

Canadian Society for Eighteenth-Century Studies / Société canadienne d'étude du dix-huitième siècle

ISSN

1209-3696 (imprimé)

1927-8284 (numérique)

Découvrir la revue

Citer cet article

Perkins, P. (2006). Scientific Amusements: Literary Representations of the Birmingham Lunar Society. Lumen, 25, 57-71. https://doi.org/10.7202/1012077ar

Copyright @ Canadian Society for Eighteenth-Century Studies / Sociéte canadienne d'étude du dix-huitième siècle, 2006
Ce document est protégé par la loi sur le droit d'auteur. L'utilisation des services d'Érudit (y compris la reproduction) est assujettie à sa politique d'utilisation que vous pouvez consulter en ligne.

https://apropos.erudit.org/fr/usagers/politique-dutilisation/ 


\section{Scientific Amusements: Literary Representations of the Birmingham Lunar Society}

At some point around the middle of the 1780s, Barthélemy Faujas de Saint-Fond, a French traveler with wide-ranging scientific interests, completed a journey through Britain by stopping in Birmingham. In the course of his visit, he had already met some of the most distinguished British thinkers of the day, and the list of people and places he visited makes the travel book he subsequently published sound like something of a scientific grand tour. While traveling near London, for example, he managed to walk in on Caroline Herschel as she was making complex astronomical calculations based on observations that her brother William was transmitting down from his observatory. Later, after going north to study the geological formations of the Hebrides, Saint-Fond was able to stop off in Edinburgh to discuss geology with James Hutton, medicine with William Cullen, and human nature with Adam Smith. Delighted as he had been by such encounters, he nonetheless decided, soon after arriving in Birmingham, that it was 'one of the most interesting towns in England. ${ }^{1}$ As he concluded, summing up his impressions of the city after meeting and dining with the scientists Joseph Priestley and James Watt, 'we may be said to have resided [here] in the midst of the arts and industry. The society of enlightened men and amiable women added new charms to our situation. Our minds were informed and delighted; our heads were filled with facts, and our hearts with gratitude. $^{2}$

This picture of Birmingham as a high point in a cultural and intellectual tour of Britain is not simply the polite gesture of a traveler using his

1 Barthélemy Faujas de Saint-Fond, Travels in England, Scotland, and the Hebrides; Undertaken for the Purpose of Examining the State of the Arts, the Sciences, Natural History and Manners in Great Britain, 2 vols. (London, 1799), 2:339.

2 Saint-Fond, 2:348. 
book to pay his social debts; Saint-Fond was by no means the only writer to be fascinated by these midlands intellectuals. On the contrary, a number of those scientists were the subjects of more or less amused commentary in a range of literature of the 1780s and 90s. Not all of the English writers were as generous as Saint-Fond in their observations, but even in mocking or critical responses, one finds an assumption that the scientific work of these men was - for good or ill — very much a part of the cultural world of the novelists and poets commenting on them and that audiences would be both engaged and amused by allusions to or representations of the cutting-edge science coming out of the Midlands. In many of these literary reconstructions of the Birmingham intellectuals, what one sees is not so much scepticism of or resistance to new and sometimes esoteric ideas, but rather an implicit or explicit celebration of scientific and philosophical exploration as a foundation for sociable engagement with the world.

The later eighteenth century would not have seen anything odd, of course, about the idea that at least some scientific experimentation would naturally be part of the wider world of civilized conversation and debate. Ladies and gentlemen of leisure made botanical collections, for example, and demonstrations of electricity briefly became something of a parlor game. ${ }^{3}$ More generally, as Alan Rauch has pointed out (admittedly, in reference to a slightly later period), ' $[t]$ he notion that science and scientists are somehow isolated within their cultures' has started to be replaced, in recent critical studies, by 'a kind of dialectic where science, literature, and culture are understood to borrow freely from each other. ${ }^{\prime 4}$ What is of particular interest in the representations of the Birmingham scientists is that their association with one another was predicated not just on the assumption that certain aspects of scientific experimentation might catch non-specialist public interest but that, more importantly, the

3 There have been a number of fairly recent studies of how women, in particular, contributed to the botanical sciences in the eighteenth and early nineteenth centuries. For a general overview of the subject, see Ann B. Shteir, Cultivating Women, Cultivating Science: Flora's Daughters and Botany in England 1760 to 1860 (Baltimore: Johns Hopkins University Press, 1996). Susan Scott Parrish provides a more focused discussion of the subject in an American context in 'Women's Nature: Curiosity, Pastoral, and the New Science in British America,' in Early American Literature 37, no. 2 (2002): 195-238. For an entertaining overview of popular interest in electricity at the time, see Patricia Fara, An Entertainment for Angels: Electricity in the Enlightenment (Cambridge: Icon Books, 2002).

4 Alan Rauch, Useful Knowledge: The Victorians, Morality, and the March of Intellect (Durham: Duke University Press, 2001), 10. 
sociable, unsystematic pursuit of ideas was in itself a constituent factor of their intellectual lives. As Saint-Fond's accounts of genial dinner parties suggests, the Birmingham intellectuals represented a mode of scientific inquiry that assumed the interconnection, rather than the gap, between sociable debate and highly specialized interests. The work of the group of friends whose cultural life Saint-Fond admired so highly spanned not only a breathtaking range of what were, at the time, both new and established sciences - including physics, chemistry, botany, geology, and medicine - but also strayed into such varied fields as educational philosophy, the applied and commercial arts, and technologies of transportation. The social links connecting this disparate association of thinkers, which included the scientists Priestley and Watt as well as the physician Erasmus Darwin, the educational theorists Richard Lovell Edgeworth and Thomas Day, and the manufacturer and philanthropist Josiah Wedgewood, are emphasized by references to them as a group under the collective name of the Birmingham Lunar Society - a name derived not from any particular interest in astronomy but rather from their practice of meeting to dine and talk on the Monday closest to the full moon, so that they would have light for the drive home.

In a recent mainstream book on the subject (perhaps surprisingly only the second so far to be published on the Lunar Society as a group ${ }^{5}$ ), Jenny Uglow suggests that this conversational exchange of ideas and the accompanying disregard for what we might now call disciplinary boundaries are precisely what made the Lunar Society as a whole an important manifestation of eighteenth-century culture. As Uglow remarks somewhat hyperbolically in her preface, this was a period in which 'you could be an inventor and designer, an experimenter and a poet, a dreamer and an entrepreneur all at once. ${ }^{6}$ The average eighteenth-century gentleman probably did not quite manage to combine all of these roles, but Uglow's point is that, just as Saint-Fond's account implies, the members of the Lunar Society embodied a vision of science that makes it part of cultured intellectual life rather than a rarified and isolating pursuit.

Granted, how exactly such investigation and debates fitted into the cultural worlds of the scientists' contemporaries is a complicated ques-

5 The earlier book on the subject is R.E. Schofield's The Lunar Society of Birmingham (Oxford: Clarendon, 1963); it provides a very detailed overview of the group from the perspective of an historian of science.

6 Jenny Uglow, Lunar Men: The Friends who Made the Future (London: Faber \& Faber, 2002), viii. 
tion, but it is one that a number of literary figures of the period explored, as they observed, even if often with an edge of mockery, the volume of scientific, educational, and technological work coming out of Birmingham and its environs. Their responses range from more or less straightforward descriptions of the scientists, of the sort that Saint-Fond offers, to parodies either of the scientists themselves - with Joseph Priestley and Erasmus Darwin particularly popular targets - or of their work. Even in parodic or mocking accounts, however, one finds not, as one perhaps might expect, that the scientists are being criticized for their detachment from the world around them, but rather that they are presented as trying too eagerly or naïvely to diffuse their ideas in the wider society. Far from anticipating the fear of isolated and isolating scientific experimentation to be found in such influential later works as Frankenstein, much of the late eighteenth-century writing that offers recognizable parodies of members of the Lunar Society focuses on the scientists' attempts to ground their cutting-edge investigations in their everyday social world. Whether they are shown as doing so by making themselves, in effect, one of the tourist attractions of their city, or by naïvely trying to demonstrate the relevance of obscure or foolish experiments, or by inappropriately crossing disciplinary boundaries in their own work, their appearances in such writing are usually built upon an assumption that it is their excessive commitment to engaging with the wider world, rather than their intellectual inaccessibility, that makes them so amusing.

The idea of a scientist as a tourist site might seem a little odd today, but there is no doubt that the members of the Lunar Society and their works were one of the major attractions of later eighteenth-century Birmingham. Saint-Fond's effusive commentary on his visit is more or less representative of the response of travelers who passed through the city in search of intellectual stimulation. In Robert Bage's 1792 novel Man as He Is, for example, the aristocratic hero makes a point of visiting Birmingham, which the narrator describes as 'a place scarcely more distinguished for useful and ornamental manufacture, than for gentlemen who excel in natural philosophy, in mechanics, and in chemistry. ${ }^{7}$ As the narrator boasts, these men and their works are almost as wellknown 'in France and Italy, Holland, Germany, and Russia' ${ }^{8}$ as they are in their own home territory, making it quite reasonable that the novel's

7 Robert Bage, Man as He Is, 4 vols. (London, 1792), 2:216.

8 Ibid, 2:216. 
touring hero would want to seek them out. Nor is he alone in this taste; Bage's impoverished but carefully educated middle-class heroine temporarily settles in Birmingham but, according to the dealer who sells the paintings by which she supports herself, she shuns all society except his and visits even him only 'when I have been favoured with the company of Dr. Priestly [sic]; with that of Mr. Keir, the well-known translator and elucidator of Macquer's Chemistry; or the celebrated author of the botanic garden [Darwin], to whom all arts and all sciences have obligation. But without some such inducement, she never stirs abroad. ${ }^{9}$ Something of a fictional counterpart to Saint-Fond, Bage's elegantly refined Miss Colerain apparently finds it impossible to disentangle her enjoyment of scientific discussions from her social life. Admittedly, Bage, who spent his entire life near Birmingham and was a long-time friend of Erasmus Darwin, might not be the most disinterested of commentators on the city's appeal, but his rhetoric is remarkably similar to that of visitors, such as Saint-Fond, who had less obvious reason to be biased. One can also turn, for evidence of the attractions of the midlands intellectuals, to the letters of William Godwin, who was so far from any sort of bias in favour of provincial culture as to be frankly surprised at the thought that someone who had never been in London could be a sophisticated intellectual. (The comment was made apropos of Robert Bage.) Yet Godwin's 1797 tour of the midlands was made at least in part to see the manufacturies and to meet with local luminaries such as Darwin. 'Are not such men,' he asks rhetorically in a letter to Mary Wollstonecraft, 'as much worth visiting as palaces, towns, and cathedrals? ${ }^{\prime 10}$

Commentary by tourists, however, is far from being the only literary record left of members of the Lunar Society; the degree of interest they attracted is perhaps even better measured by their more or less recognizable appearance in works that are not directly about either Birmingham or science. William Blake, for example, whose 'dark satanic mills' have - admittedly, in an oversimplified manner - become a form of dismissive shorthand for the industrialization shaped at least in part by the work of the Birmingham intellectuals, was sufficiently aware of and interested in the sort of work that they were doing to mock at least one version of their scientific experimentation in an early, relatively gentle parody. Probably written around 1784, Blake's fragmentary farce $A n$

9 Ibid, 2:219-20.

10 C. Kegan Paul, ed., William Godwin: His Friends and Contemporaries, 2 vols. 1876 (New York: AMS Press, 1970), 1:261. 
Island in the Moon features a character named Inflammable Gass, who has been read as, among other things, a farcical hit at Joseph Priestley, whom Blake might in fact have known (he was certainly acquainted with Erasmus Darwin). Granted, the link between Inflammable Gass and Priestley is tenuous, as scholars have both suggested other models and argued against the likelihood of Blake having Priestley specifically in mind, ${ }^{11}$ but whether or not Blake was mocking Priestley directly, there is little doubt that contemporaries would have seen him as the most famous example of the type of thinker being targeted by Blake. The name in itself is a fairly direct link, as even though Priestley was by no means the only late eighteenth-century experimentor with oxygen - or, as it was then called, inflammable gas - the notoriety he gained through his religious and political radicalism helped to ensure that he was perhaps the best known.

Despite its parodic manner, Blake's Island is, however, in no way an attack on Priestley or scientists of his sort. On the contrary, the work conveys, despite its farcical exaggeration, a version of scientific exploration that is marked by a sort of cheery, even if on occasion slightly alarming, sociability. In one scene, which gives a flavour of the work as a whole, Inflammable Gass sets up a demonstration of his experiments to entertain some visitors, but things rapidly go wrong:

While Tilly Lally \& Scopprell were pumping at the air pump Smack went the glass. - Hang said Tilly Lally. Inflammable Gass turnd short round \& threw down the table \& Glasses \& Pictures, \& let out the Pestilence. He saw the Pestilence fly out of the bottle \& cried out while he ran out of the room. come out come out we are putrified, we are corrupted. our lungs are destroyed with the Flogiston this will spread a plague all thro' the Island $[\ldots]^{12}$

Beneath the anarchically overwrought language and action, one finds in this passage a glimpse of a type of scientific sociability more familiar from the paintings of Joseph Wright of Derby, in which more or less

11 S. Foster Damon, in A Blake Dictionary, matter-of-factly identified Inflammable Gass as Priestley, but as David Erdman showed as long as half a century ago, there is nothing straightforward in even such a minor point of Blake scholarship, and the question of whether Inflammable Gass should be read as Priestley or not was even then being hotly debated. See Blake: Prophet Against Empire (New York: Dovers, 1954; 1991), 93-94, 105-109.

12 William Blake, An Island in the Moon, in Blake's Complete Poetry and Prose, ed. David Erdman. Rev. ed. (New York: Anchor Books, 1982), 462. 
austere scientists manipulate esoteric-looking glass or metal instruments and demonstrate their craft to fascinated or appalled audiences. In particular, given the mention of the 'air pump' (which late eighteenthcentury readers would almost certainly have connected directly or indirectly with Priestley's experiments with oxygen), one might think of Wright's famous image of a dying bird in a glass balloon from which the oxygen has just been removed. Even though Wright's image predates Priestley's most famous work, it gives an influential visual sense of the interplay of science and sociability in roughly the period and geographic area in which Priestley was working. Nor was Wright alone in his fascination with such instruments; Saint-Fond describes, in considerable detail, the 'ingenious apparatus' that Priestley has set up 'for making experiments on inflammable gas,' finding them of sufficient interest to make careful drawings for his friends in France. ${ }^{13}$

What one finds here, in these representations of experiments with oxygen, whether by Priestley himself or by those who shared his interests, is a sense of the variety of ways in which more or less abstruse and cutting-edge science could be incorporated into the wider cultural discourse. Wright's focus is, first of all, on the visual drama and then on the moral implications of the act of experimenting, not on the results. SaintFond, though a man of science himself, is writing his travels for an audience that (presumably) is interested generally in British intellectual life and culture, not in the specifics of the scientific work that he is observing. Significantly, he repeatedly mentions but chooses not to reproduce the drawings that he makes of scientific instruments. Blake, of course, uses the experiments as an occasion for simple farce. Yet as varied as these representations are, they avoid the two extremes that one might expect to be evoked by what would, to most, be more or less incomprehensible research: respectful and distant awe, or fear and horror. A strictly literal-minded reading of Blake's passage could perhaps see it as touching on the potential danger of irresponsible experimentation, as Inflammable Gass accidentally releases 'a plague all thro' the island,' but any such attempts at critical solemnity would be difficult to sustain in the face of the hyperbolic farce of the scene. No less importantly, Inflammable Gass's experiments are, like those of Wright's scientists, explicitly social and performative, bringing him into human contact rather than isolating him from it. As Erdman noted long ago, the char- 
acters of Island in the Moon live in a world that is insistently structured around domestic sociability and camaraderie. ${ }^{14}$

Likewise, if the image of the dying bird and horrified children can be read as critical of scientific experimentation, Wright has other paintings in which the scientist is a far more obviously sympathetic figure (for example, Philosopher Giving a Lecture on the Orrery [c. 1768]). Yet even Experiment with an Air-Pump is far from being unproblematically critical in its treatment of the scientist. Albert Boime, for one, has argued that even if there is something 'macabre' in the 'haggard' central figure, Wright is nonetheless transforming ' $t \mathrm{t}]$ he religious awe of older painting' by reinventing it as 'the awe of unlimited possibilities promised by moonlit science. ${ }^{15}$ While there is no question that later eighteenth-century science could on occasion invite blindly hostile fear and hatred - as the rioters who, in 1791, smashed Priestley's laboratory demonstrated in the most concrete way possible - what one finds in the more sophisticated artistic and literary representations of the Birmingham intellectuals is a sense that they and their work are part of the general cultural world and as such are entirely appropriate material for poets and novelists to incorporate into their own writing.

This point is made even through work that might seem, at first glance, much more straightforwardly mocking in its approach to ideas associated with members of the Lunar Society. To begin with a relatively familiar example, one can look at Maria Edgeworth's satiric treatment of one of the more notorious social experiments of her father's eccentric friend, Thomas Day - his disastrous attempt, following a somewhat painfully literal-minded reading of Emile, to raise and educate a bride for himself. In her 1801 novel Belinda, Edgeworth recreates a version of Day in the figure of her hero Clarence, who, 'charmed with the picture of [Rousseau's] Sophia [.. . ] formed the romantic project of educating a wife for himself' and sets out to turn a beautiful, chance-met orphan into the perfect bride. ${ }^{16}$ The incident invites mockery, yet instead of reimagining Day as a simple figure of fun, Edgeworth makes this passionate, if misguided, engagement with ideas part of Clarence's charm. This relative gentleness with her target is not simply a result of family friendship; as Edgeworth demonstrated in her first published work, Letters for

14 Erdman, Prophet against Empire, 95-98.

15 Albert Boime, Art in an Age of Revolution 1750-1800 (Chicago: University of Chicago Press, 1987), 240.

16 Maria Edgeworth, Belinda (Oxford: Oxford University Press, 1999), 362. 
Literary Ladies (1795), she was capable of being thoroughly scathing in her treatment of Day's convictions. In the earlier work, the ideas of a character who is, in effect, a mouthpiece for Day's anti-feminist views on female education are politely, but thoroughly, demolished by the rebuttal of a speaker who - sounding remarkably like Richard Lovell Edgeworth - outlines and defends his ambitious plans for his daughter's education.

By the time she wrote Belinda, however, Edgeworth was prepared to show her idealized version of Day as failing through his excessively enthusiastic commitment to an intellectual system rather than through simple misogynistic prejudice. When, for example, Clarence is moved to enthusiastic bliss by his pupil's lack of interest in diamond jewellery, the narrator, insisting that Virginia's indifference is more or less meaningless given her almost total isolation from society, comments dryly that such 'reflections could not possibly have escaped a man of Clarence Hervey's abilities; had he not been engaged in defence of a favorite system of education, or if his pupil had not been quite so handsome. ${ }^{17}$ Clarence's enthusiasm and delight, as he convinces himself that Virginia is the embodiment of untutored virtue, is of course undercut by the folly that the narrator is so careful to stress. Yet at the same time, Clarence's impassioned attempt to prove experimentally the 'system' of natural virtue, in which he so desperately wants to believe, demonstrates his own virtuous, if somewhat paradoxical, attempt to bring together his philosophical scepticism about the moral groundings of society and his own social practices. Rather than being led away from his social world by his relatively abstruse philosophical and educational theories, Clarence is able to learn better how to take his place in that world because he investigates and experiments with the systems that ground the moral practice of his society rather than simply absorbing and following them on faith. While readily admitting that the spirit of intellectual investigation can lead to some ridiculous actions, Edgeworth suggests, equally strongly, that the most admirable people in her world are those who have the curiosity and the daring to explore new ideas, even at the risk of looking like a fool.

One finds a somewhat different and perhaps slightly more complex version of this double-edged treatment of intellectual exploration in Robert Bage's 1788 novel James Wallace. Unlike Edgeworth, who focuses on the more philosophical-minded members of the Lunar Society, Bage 
turns his attention directly to the sort of scientific and technological research for which the Birmingham intellectuals became best known, featuring a character who rivals Edgeworth's Clarence in his preoccupation with new ideas but who makes himself even more ridiculous as he repeatedly and gullibly attempts to transform his life and world through technology. On hearing, for example, that a French agriculturalist has improved his yield by running an electrical current through his fruit trees, Bage's Mr. Holman, disdaining 'the hacknied mode of manure,' sets out to improve his own crops by electrifying them with what is, in effect, a gigantic Leyden jar; the result, unsurprisingly, is expensive disaster. ${ }^{18}$ Holman is also probably the first character in literature to be concerned about establishing aerial superiority in warfare, as a chance comment leads him to panic about French invasion by hot-air balloon. In this mocking treatment of a character driven by a monomaniacal obsession with the new, Bage might seem to be anticipating in technique, if not in his target, the attacks on the radical philosophers that were made in the next decade by anti-jacobin novelists. When Mr. Holman sets out to grow fruit by electricity, he could on some level be read as a direct forebear of, for example, the philosophers in Elizabeth Hamilton's Translations of the Letters of a Hindoo Rajah (1796), who attempt to find new sources of honey by educating sparrows to swarm like bees. Yet there are also important differences, not the least being that Bage presents Holman's obsessions through the sceptical eyes of his son Paracelsus, who is angered and infuriated by his father's manias - not because he does not believe in the importance of scientific investigation, but rather because of the way that Holman senior uses science as an excuse for narrowing, rather than widening, his understanding of the world around him. As Paracelsus, himself a doctor and an amateur chemist, exclaims impatiently after describing his father's latest obsession, his 'eternal adoption of system' is a mark of 'the weakness of [his] philosophy. ${ }^{\prime 19}$

Bage makes very clear that Holman senior's problems are not that he is excited by the possibilities of the new sciences, but that, somewhat ironically, he uses those ideas to shut down, rather than open up, intellectual debate. What Bage is mocking here is not scientific investigation in itself, but rather an attitude that sees science as a mysterious system of knowledge that gives quasi-magical powers to its disciples. If Edgeworth's Clarence is ruled by system to the point that he is blinded

18 Robert Bage, James Wallace, 3 vols. (London, 1788), 1:75.

19 Ibid, 1:76. 
to his own logical fallacies, Holman senior goes a step further and treats science as a matter of wide-eyed faith rather than of sceptical investigation. Notably, Bage gives Holman, as his counterpart, a devoutly Calvinist wife whose unquestioning devotion to her religious beliefs parallels exactly his faith in science. What might, in other words, initially seem to be a straightforward parody of scientific investigation turns into a rather more complex celebration of a particular version of intellectual inquiry, one that rejects both obscurantism and a blind devotion to innovation in and for itself. This point is made clear by Bage's inclusion, as a contrast to the easily befuddled and bedazzled Holman senior, of the deeply sceptical but witty, engaging, and intellectually curious Paracelsus. While Paracelsus is, admittedly, too slightly developed as a character to see him as being drawn from any particular model, it is reasonable to speculate that, in creating a successful, free-thinking, and independentminded doctor with wide-ranging literary and scientific interests, Bage might have had at least some aspects of Erasmus Darwin in mind. At the very least, it seems safe to say that it is Paracelsus, with his open-minded and questioning intellect, and not his narrow, easily panicked father, who is the character closest in spirit to the members of the Lunar Society.

Yet if Paracelsus Holman suggests Bage's sympathetic attitude towards the intellectual tone of the Lunar Society in general and perhaps Erasmus Darwin in particular, not all of Darwin's contemporaries were as warm in their evaluation of Darwin's ideas and attitudes. In particular, a number of writers gleefully attacked or parodied Loves of the Plants (1789), a work in which Darwin attempted to convey an idea of the Linnaean system of classification by writing an erotic poem about plant reproduction. Loves of the Plants is an odd work by any standards, combining a lushly sentimental style of poetry that would not be out of place among the Della Cruscians with notes that pack in a remarkable range of botanical and cultural information on the appearance and uses of the plant in question. As Darwin explains in an advertisement, "The general design of the following sheets is to inlist Imagination under the banner of Science, and to lead her votaries from the looser analogies, which dress out the imagery of poetry, to the stricter ones, which form the ratiocination of philosophy. ${ }^{20}$ The first plant he mentions, the Indian Reed, provides a good illustration of his method, as he begins by imagining its single stamen and pistil as a picturesquely devoted married couple:

20 Erasmus Darwin, The Botanic Garden, Part 2. Containing The Loves of the Plants. A Poem. With Philosophical Notes (London, 1791). 
the tall CANNA lifts his curled brow

Erect to heaven, and plights his nuptial vow;

The virtuous pair, in milder regions born,

Dread the rude blast of Autumn's icy morn;

Round the chill fair he folds his crimson vest,

And clasps the timorous beauty to his breast. ${ }^{21}$

In a note, Darwin then explains his imagery, commenting on both the 'beautiful crimson flower' of the semi-tropical plant and the use of the seed for shot or for rosary beads. If not unique in its attempt to bring together the languages of botanical science and of poetry - William Bartram's popular and very influential journals of his travels in the southern states of America, which were published in 1791, did very much the same thing ${ }^{22}$ - Darwin's portrayal of variously blushing, retiring, oversexed or flauntingly polyamorous plants nonetheless caught the attention of his contemporaries in its slyly comic portrayal of an intensely and comprehensively eroticized scientific system. ${ }^{23}$

One reaction to this attempt was predictable enough: bringing rather over-heated, if comic, eroticism to a book that combined the two stereotypically feminine interests of flower-gathering and poetry inevitably led to some more or less furious attacks on Darwin for undermining female delicacy. Darwin was both reaching out to and attracting a female audience through his work, ${ }^{24}$ and even though (as critics such as Ann

21 Erasmus Darwin, Loves of the Plants, canto 1, lines 39-45.

22 William Bartram, Travels through North $\mathcal{E}$ South Carolina, Georgia, East $\mathcal{E}$ West Florida (Harmondsworth: Penguin, 1996). Like Darwin, Bartram shifts register between pastoral language and scientific terminology in a manner that can at first seem jarring; at one point, for example, writing lyrically about a place where he camped for a night, Bartram recalls listening to 'the responsive cooings of the innocent doves, in the fragrant zanthoxylon groves' as 'I repose[d] on my sweet and healthy couch of the soft tillandsia usnea-adscites' (141).

23 The ironic and, to a lesser extent, the comic elements of Darwin's poetic style have been noted and analysed by Donald M. Hassler, who comments on both the 'consciously humorous' aspects of Darwin's treatments of natural processes and the 'playful, speculative, and skeptical elements' of his writing as a whole. See The Comedian as the Letter D: Erasmus Darwin's Comic Materialism (The Hague: Martinue Nijhoff, 1973), 84, 50 .

24 Shteir discusses both Darwin's general interest in attracting women readers - even while pointing out the conventionality of his gender politics (26-67) - and his impact on individual women botanists, such as Maria Jacson (110-16). 
Shteir have pointed out) his gender politics were not particularly progressive, he was the subject of some intensely hostile commentary for 'unsexing' his young women readers by encouraging them - in Richard Polwhele's notorious phrase - to 'point the prostitution of a plant. ${ }^{25}$ Few, it seems, would have agreed that Darwin succeeded in his goal of moving from 'looser analogies' to strict philosophy. Yet it was not only for his supposedly dangerous impact on women readers that Darwin was attacked. Somewhat less obvious, perhaps, was the approach taken by The Anti-Jacobin, at least as represented in the work of George Canning and John Hookham Frere, who responded to Darwin with their own pseudo-erotic poem, The Loves of the Triangles (1799). In this work, Darwin's attempt to bring scientific terminology to a wider cultural readership is one of the main targets of satire; Canning and Frere mock the very idea that the sort of popular verse that Darwin was writing could provide any sort of serious or rigourous examination of intellectual systems.

Ostensibly, Loves of the Triangles is a direct rebuke to the unsystematic transgression of intellectual boundaries implicit in Loves of the Plants, as the poem opens with a stern injunction to the 'sons of War and Trade' as well as 'the legion fiends of Church and Law' to refrain from invading 'the Muse's haunts.' As the speaker explains to those he is dismissing, 'To you no Postulates prefer their claim, / No ardent Axioms your dull souls inflame; / For you, no Tangents touch, no Angles meet, / No Circles join in osculation sweet!' ${ }^{26}$ Poetry, it appears, is the sole province of the mathematician. The joke is obvious, yet it is also double-edged: as The Anti-Jacobin poets demonstrate their ingenuity by explaining, in neat heroic couplets and classically-inflected diction, how the 'conjugated axes' of the hyperbola differentiate it from the parabola, ${ }^{27}$ what is designed as a deliberately heightened and self-consciously absurd mockery of Darwin's attempt to combine poetry and science ends by suggesting just how flexible the language of poetry actually is. The point is not that anybody would set out to learn mathematical terminology through a close reading of Loves of the Triangles - and of course one might also wonder how much serious botany anybody ever absorbed

26 John Hookham Frere and George Canning, Loves of the Triangles, in John Hookham Frere, Works (London, 1872), lines 2-3, 7-10.

27 Frere and Canning, Loves of the Triangles, lines 110-26. 
through a reading of Loves of the Plants - but rather that Canning and Frere assume an audience equally comfortable with the languages of mathematics and poetry. The jokes in Loves of the Triangles fall distinctly flat if one does not know the mathematical shapes that the poets are imagining in more or less lascivious poses, and while the satire moves far beyond the conceit of the title (it ends with a vision of the guillotining of William Pitt), much of the poem assumes a reader of precisely the sort of wide-ranging interests that Darwin was aiming for and perhaps hoping to create through his poetry.

The specific ideas of the Birmingham scientists might thus have been unattractive to a number of their contemporaries; certainly, as the 1790s progressed and reaction against the French Revolution hardened, suspicion of political free-thinking seemed to feed into a distrust of the Birmingham scientists and their mode of open, wide-ranging intellectual exploration. By the end of the decade, Canning and Frere would have been by no means alone in their fears that an enthusiastic love of triangles - or plants, or electricity, or oxygen - might be entirely continuous with a love of the guillotine and all that it represented. Yet even while they implacably oppose Darwin's political views and mock his attempt to merge science and poetry, Canning and Frere are unable to avoid echoing his technique in merging, with dazzling verve, the languages of two very different intellectual systems. They, of course, are entirely satiric in their union of mathematics and erotic verse, and thereby ratchet Darwin's gentle comedy up by several notches, but even so, their wildly inventive, asystematic transgression of boundaries is tonally, if not politically, in harmony with the poem and the poet whom they are mocking. In this respect, they are as much part of the mood of intellectual excitement caught by Saint-Fond in his brief portrait of the Birmingham scientists as they are of the reaction against it. There is no doubt that, given their political views, the poets of The Anti-Jacobin make rather odd company with Erasmus Darwin, or even with William Blake, Robert Bage, or Maria Edgeworth. Yet in taking up, in their own writing, ideas or approaches associated with various members of the Birmingham Lunar Society, all of these writers, Canning and Frere not excepted, demonstrate a shared assumption that scientific work was not a discourse that was entirely distinct from that of the literary culture in which they moved. With the partial exception of Loves of the Triangles, this work indicates neither suspicion of nor automatic hostility to what would have been at the time some of the more implausible edges of scientific thought. Rather, it suggests a wider cultural interest in fairly esoteric research. Even while treating these subjects in a parodic manner, the authors whom I have been discussing assume that the audience for the sort of popular literature that they are writing will find them 
both interesting and accessible. In that respect, these contemporary glances at members of the Lunar Society embody much the same values as those represented by the Lunar Society itself - a playful, lively curiosity about matters that transgress intellectual systems and disciplinary boundaries.

PAM PERKINS

University of Manitoba 